\title{
SERUM MICRO- AND MACROELEMENTS LEVELS IN WOMEN WITH POLYCYSTIC OVARY SYNDROME ASSOCIATED WITH PELVIC INFLAMMATORY DISEASE
}

\section{T.F. TATARCHUK \\ $M D$, professor, corresponding member of NAMS of Ukraine, deputy director for research work, Chief of the Endocrine Gynecology Department, State Institution "Institute of \\ Pediatrics, Obstetrics and Gynecology of the NAMS of Ukraine"}

ORCID: 0000-0002-5498-4143

\section{N.V. KOSEI}

$M D$, chief researcher at the Endocrine Gynecology Department, SI "Institute of Pediatrics, Obstetrics and Gynecology of the NAMS of Ukraine" ORCID: 0000-0003-3085-3285

\section{H.V. VETOKH}

Obstetrician-gynecologist, Antenatal clinic № 3, Advisory and Diagnostic Centre of the Dniprovskyi district of Kyiv ORCID: 0000-0003-3551-2041

\section{S.V. GUNKOV}

PhD, leading researcher, State Enterprise "Scientific Centre of Preventive Toxicology, Nutritional and Chemical Safety named after L.I. Medved"

ORCID: 0000-0002-1921-7272

\section{Contacts:}

Halyna V. Vetokh

Antenatal clinic № 3 ,

Advisory and Diagnostic Centre of the Dniprovskyi district of Kyiv Chervonotkatska str. 31, 02004, Kyiv

tel.: +38 (044) 5590122

e-mail: AlinaVetokh@gmail.com

\section{INTRODUCTION}

Polycystic ovary syndrome (PCOS) is a common disease with incidence of $5-10 \%$ among women of fertile age [1]. This disorder is multifactorial. It was previously thought that PCOS is a disease of women of fertile age only. However, the last years' studies revealed that reproductive age disorders go alongside women throughout their life [2].

\section{ANALYSIS OF PUBLISHED DATA AND RESEARCH OBJECTIVE}

In fact, human body contains $3 \%$ of metals [7]. Their content varies from a couple of micrograms to a couple of grams [8]. Though 69 metals are presented in cells in different amounts, all of them play an important role in different processes within the human body [5]. Biometals are included into enzymes or coenzymes, controlling wide range of energy and constructive metabolism reactions, and also act like compounds or coordinators of specific cellular functions of the main body tissues [10].

The most important feature of chemical elements' function within human body is their interaction with each other. This interaction often manifests in forms of synergic or antagonistic effects [9] (Picture 1).

Despite essential microelements are necessary for providing body's life sustenance, they may demonstrate toxic properties in high concentrations. There are only limited amount of scientific works in foreign literature concerning serum levels of microelements in PCOS. Moreover, their results are often controversial. In Ukraine such studies have not been performed yet. For this reason, the objective of this study was to determine the serum levels of some essential macro- and microelements in patients with PCOS. Taking into account high coincidence of PCOS and inflammatory disorders of genital tract, it was decided to explore microelements levels in this category of patients as well.

\section{MATERIAL AND METHODS OF THE STUDY}

Three groups of women were included into the study: 30 women with polycystic ovarian syndrome associated with pelvic inflammatory disease (I group), 22 patients with polycystic ovarian syndrome without pelvic inflammatory disease (II group), and 25 healthy women (III group).

In all groups serum levels of next macro- and microelements were determined: magnesium $(\mathrm{Mg})$, copper (Cu), manganese (Mn), nickel (Ni), zinc $(\mathrm{Zn})$, chromium (Cr), selenium (Se), vanadium (V).

Microelements studies were performed in an accredited laboratory of Scientific Centre of Preventive Toxicology, Nutritional and Chemical Safety named after L.I. Medved according to validated methodology according to Methodical Instruction 4.1.1483-03. Approximately $3 \mathrm{ml}$ of serum were used for performing of tests. After microwave-based mineralization samples were analyzed in mass-spectrometer with inductively binded plasma Bruker MS 820 (Australia) using special software ICPMS Expert.

Statistical data processing was performed using software Statistika 6.0. Median value, 95th percentile, and mean value $(M)$ were counted. In order to access statistical significance of data obtained (P) Mann-Whitney U-test, KolmogorovSmirnov test, and Student t-test were used.

\section{RESULT OF THE STUDY AND DISCUSSION}

Based on the research findings, PCOS women had deviations in serum microelements levels in comparison to the control group (Table), namely increased levels of nickel, zinc, and manganese.

Magnesium plays a very important role in regulation of metabolism, as well as functioning of central nervous, cardiovascular and other body systems. Data on magnesium role in PCOS development are highly controversial. While some authors claim that magnesium takes part in PCOS genesis, even though they mostly associate these changes with impaired glucose metabolism [5], others argue against it [6]. Our studies demonstrated that in PCOS women, irrespective of presence or absence of pelvic inflammatory disease, serum magnesium concentrations were comparable to those in control group.

Role of copper in regulation of hypothalamicpituitary axis functioning was proven in a great number of works. It was demonstrated that in PCOS women serum copper level increases [6]. Recent studies confirmed that apart from hormonal disorders, changes in serum copper are associated with oxidative stress activation, in which copper acts as a catalyst. In our explorations it was demonstrated that in PCOS women there was a tendency towards increase of copper serum level (I group - median $0.88 \mathrm{~g} / \mathrm{l}$ and II group median $0.86 \mathrm{~g} / \mathrm{l}$ ) in comparison to control group (median 
$0.81 \mathrm{~g} / \mathrm{l})\left(\mathrm{p}_{1-3 ; 2-3}<0.05\right)$. However, no significant differences were revealed.

Besides copper, zinc is also of great concern in oxidative stress genesis being included into the structure of numerous enzymes and hormones. Both microelements are included into the structure of $\mathrm{Cu} / \mathrm{Zn}$-superoxide dismutase - an antioxidant enzyme. Also, zinc is accumulated in human body as part of specific, cysteine-rich proteins - metallothioneins which are able to bind other metals as well. It is known that zinc is a potent inductor of metallothionein synthesis in human cells [12]. Therewith, metallothionein synthesis in human and animal cells increases under the influence of other heavy metals as well as other factors like oxidative stress, heat exposure, injury, radiation, hypoxia, some cytokines like interleykin (IL)-1, IL-6, tumor necrosis factor (TNF-a), interferon- $\gamma$ (IFN- $\gamma$ ) [13]. In our previous study the increase of interleykin-18 was demonstrated in PCOS women with PID, this cytokine is known to affect the inflammatory disease development: it stimulates production of TNF- $\alpha$, IL-2, IFN $\gamma$, and activates cells of the monocyte-macrophage system [13].

Metabolic pathways of zinc and metallothioneins within a cell are strictly connected. Zinc sulfas intoxication was demonstrated to cause decrease in antioxidant enzymes activity [12, 13]. Probably, this might be described as adaptive reaction of human body (Picture 2).

The literature data about zinc levels in PCOS are controversial. Some investigators revealed decrease in zinc serum levels in women with polycystic ovarian syndrome [7, 8]. However, our studies gave evidences of increased zinc serum levels in PCOS women with and without pelvic inflammatory disease (I group median $0.659 \mathrm{~g} / \mathrm{l}$, II group median $0.648 \mathrm{~g} / \mathrm{l})$, in comparison to control group (median $0.442 \mathrm{~g} / \mathrm{l})\left(\mathrm{p}_{1-3,2-3}<0.05\right)$. These findings correspond to results obtained by Chakraborty P. et al. (2013) and Kurdoglu Z. et al. (2012), who also observed increased level of this microelement in PCOS women $[5,6]$.

Besides zinc and copper, one more microelement - manganese participates in oxidative stress-related processes. Cations of this microelement damage cellular membranes through the activation of oxidative processes. Destruction of plasmatic cellular membrane may lead to changes in cellular receptors function and inversion of cell's reaction on internal regulatory signals. In such a case the function of mitochondrial membranous structures is also damaged which leads to damaged energetic metabolism of cells and their functional activity. All these changes may lead to development of morbid conditions. Manganese ions are able

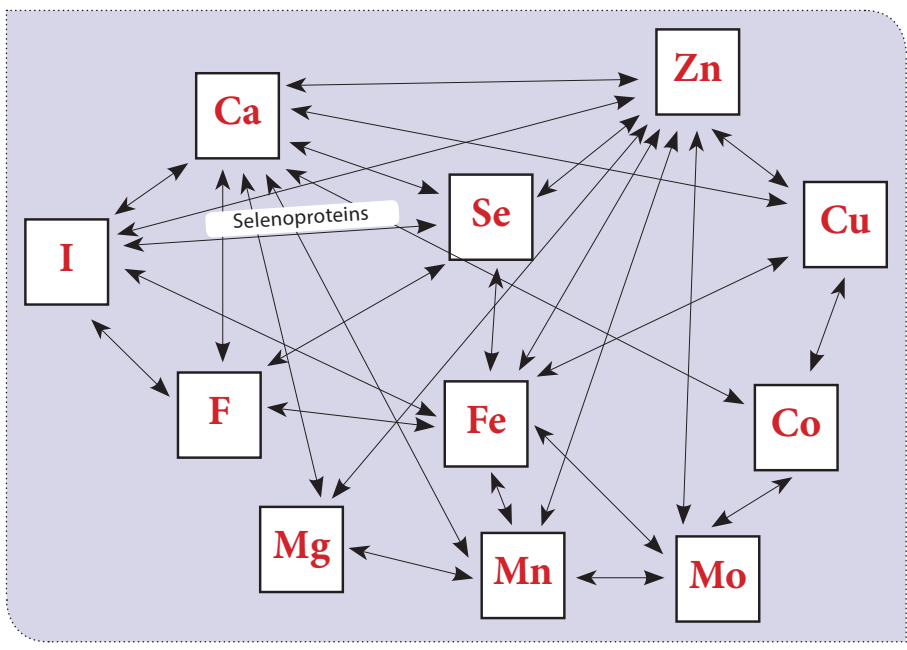

PICTURE 1. MICROELEMENTS' EFFECTS COORDINATION

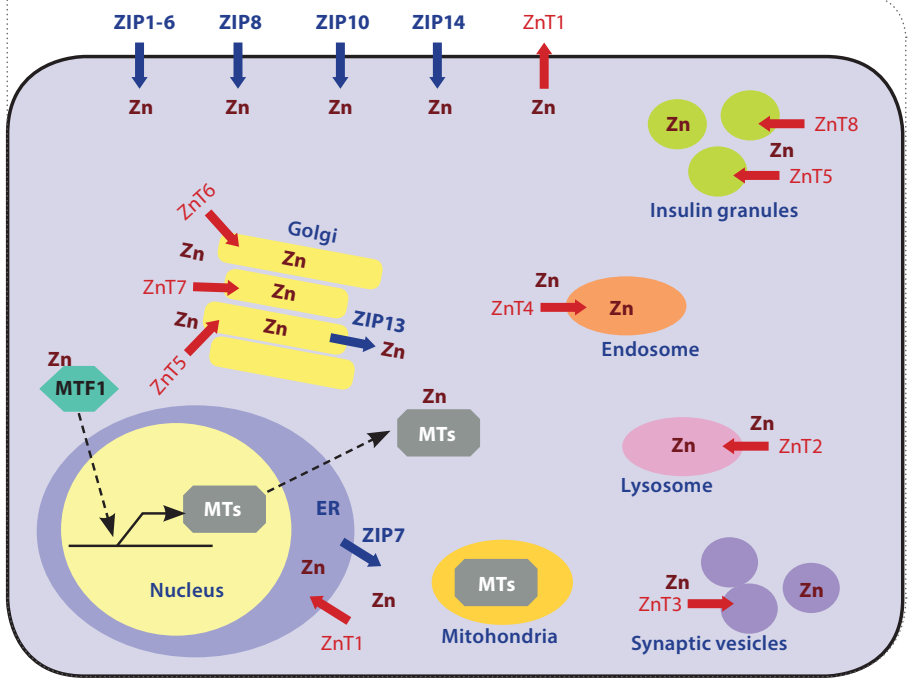

PICTURE 2. INTRACELLULAR LOCALIZATION OF ZINC TRANSPORTERS AND METALLOTHIONEINS

MTs - metallothioneins; MTF1 - metalsensitive element-binding transcription factor; ZIP (blue) and $\mathrm{T}$ (red) - zinc transport proteins; ER - endoplasmic reticulum

to replace magnesium ions in enzymatic reactions. However, because of different size of these ions a lot of errors occur; for instance, in phosphotransferase reactions while reading of DNA and RNA matrices by DNA and RNA-polymerases.

Some studies revealed that manganese may be involved into the process of glucose metabolism aberrations in PCOS women. According to Kurdoglu Z. et al. (2012) serum manganese

TABLE. SERUM MACRO- AND MICROELEMENTS LEVELS IN WOMEN, g/l

\begin{tabular}{|c|c|c|c|c|c|c|c|c|c|}
\hline \multirow{2}{*}{ Elements } & \multicolumn{3}{|c|}{ I group, $n=30$} & \multicolumn{3}{|c|}{ II group, $n=22$} & \multicolumn{3}{|c|}{ III group, $n=25$} \\
\hline & Median & 95-th percentile & M & Median & 95-th percentile & M & Median & 95-th percentile & M \\
\hline Magnesium & 22.4 & 75.1 & 28.11 & 22.4 & 75.1 & 28.11 & 21.59 & 85.35 & 26.78 \\
\hline Copper & 0.88 & 1.54 & 0.92 & 0.86 & 1.49 & 0.97 & 0.81 & 1.62 & 0.84 \\
\hline Manganese & $0.0098^{*}$ & 0.16 & 0.035 & $0.0094^{*}$ & 0.12 & 0.032 & 0.0035 & 0.014 & 0.0056 \\
\hline Nickel & $0.046^{*, * *}$ & 0.198 & 0.064 & $0.032^{*}$ & 0.185 & 0.051 & 0.001 & 0.097 & 0.013 \\
\hline Zinc & $0.659^{*}$ & 1.68 & 0.763 & $0.648^{*}$ & 1.59 & 0.751 & 0.442 & 0.65 & 0.46 \\
\hline Chrome & 0.054 & 0.25 & 0.083 & 0.05 & 0.25 & 0.085 & 0.069 & 0.25 & 0.086 \\
\hline Selenium & 0.084 & 0.32 & 0.118 & 0.087 & 0.39 & 0.111 & 0.093 & 0.62 & 0.129 \\
\hline Vanadium & 0.0116 & 0.063 & 0.019 & 0.0127 & 0.059 & 0.019 & 0.01 & 0.058 & 0.019 \\
\hline
\end{tabular}


levels were decreased in PCOS women [6]. Authors revealed strengthening of manganese deficiency in case of insulinresistance. Majority of authors explain these changes by manganese deficiency in meal and recommend including manganese into diet. Studies performed gave evidences of lower manganese serum concentration in PCOS patients, for example, in control group of women median manganese concentration was $0.0035 \mathrm{~g} / \mathrm{l}$, whereas in PCOS women groups it was 0.0098 $\mathrm{g} / \mathrm{l}$ in I group and $0.0094 \mathrm{~g} / \mathrm{I}$ in II group, the difference was statistically significant $\left(\mathrm{p}_{1-4 ; 2-4}<0.05\right)$.

Despite nickel was included by the WHO into the group of possibly essential microelements, literature data about its role in reproductive function regulation are practically absent. However, it is known that nickel is also able to induce free-radical oxidation in cellular membranes (Picture 3).

We found the single work of Chinese investigators which revealed increase in serum nickel levels in PCOS women [7]. This direction of changes was confirmed by the results of our own study. In I group of women was revealed significant increase in nickel serum concentration with median of 0.046 $\mathrm{g} / \mathrm{l}$ in comparison to II group median of $0.032 \mathrm{~g} / \mathrm{I}$ and III group median of $0.001 \mathrm{~g} / \mathrm{l}\left(\mathrm{p}_{1-2,1-3}<0.0001\right)$. Significant difference was also revealed while comparing of data from groups II and III. It is known that this microelement is able to cause dysfunction of cellular membranes and mitochondria, DNA molecules rupture with damage of transcription and RNA synthesis, and modification of metabolism of lipids and proteins, including enzymes. For these reasons accumulation of excessive amount of nickel may participate in damaging of folliculogenesis and ovulation in PCOS patients.

By virtue of its ability to change macrophages functional activity, inhibit natural killers, as well as induce inflammation, this metal is able to promote the reproductive tract's inflammation and its chronization in this category of women.

Until now, it was unclear, whether chromium is involved into development of genital tract's pathology [9]. Changes described are rather connected with disturbances of glucose metabolism. According to Chakraborty P. et al., in PCOS patients decrease in serum levels chromium was observed in women with insulin resistance [5]. At the same time, in other work no changes in serum chromium levels were demonstrated [7].

The role of selenium in pathogenesis of this disease also remains uncertain. Turkish studies showed decrease in serum selenium in hyperandrogenic women [10]. At the same time, Polish investigations did not prove any changes of serum selenium in women with PCOS [11]. Our studies are also failed to demonstrate any selenium level differences between both groups of women.

Our studies showed that vanadium serum levels have not differed in both groups of women, which corresponds to data obtained in other countries [7].

\section{CONCLUSIONS}

Revealed increase in zinc and nickel levels, as well as decrease in serum manganese in PCOS, might indicate their potential role in depression of folliculogenesis and ovulation processes, especially in light of known abilities of these microelements to activate lipid peroxidation, to decrease antioxidant systems activity, to cause damage of cellular membranes and mitochondria, to disrupt DNA molecules, and damage transcription processes. Relatively higher concentrations of zinc and nickel in PCOS associated with inflammatory disease, are indicative of the possible role of inflammation in development of disorder, as pro-inflammatory cytokines (IL-1, IL-6, IL-18, TNF-a) promote zinc accumulation, whereas increased nickel levels may induce inflammation and inhibit macrophages and natural killers activity, which leads to chronicity of inflammatory disease.

In view of the foregoing, determination of serum zinc, nickel, and manganese levels, as well as control of these elements content in complex multivitamin supplements might be recommended for women with PCOS associated with inflammatory disease. Dietary intake of manganese-rich products (such as bananas, blueberry, currants, raspberry, potatoes, beets, and nuts) alongside with decrease in zinc-containing (seafood, screenings, pulses) and nickel-containing (chocolate, cacao, soya, pulses) products intake might be recommended as well.

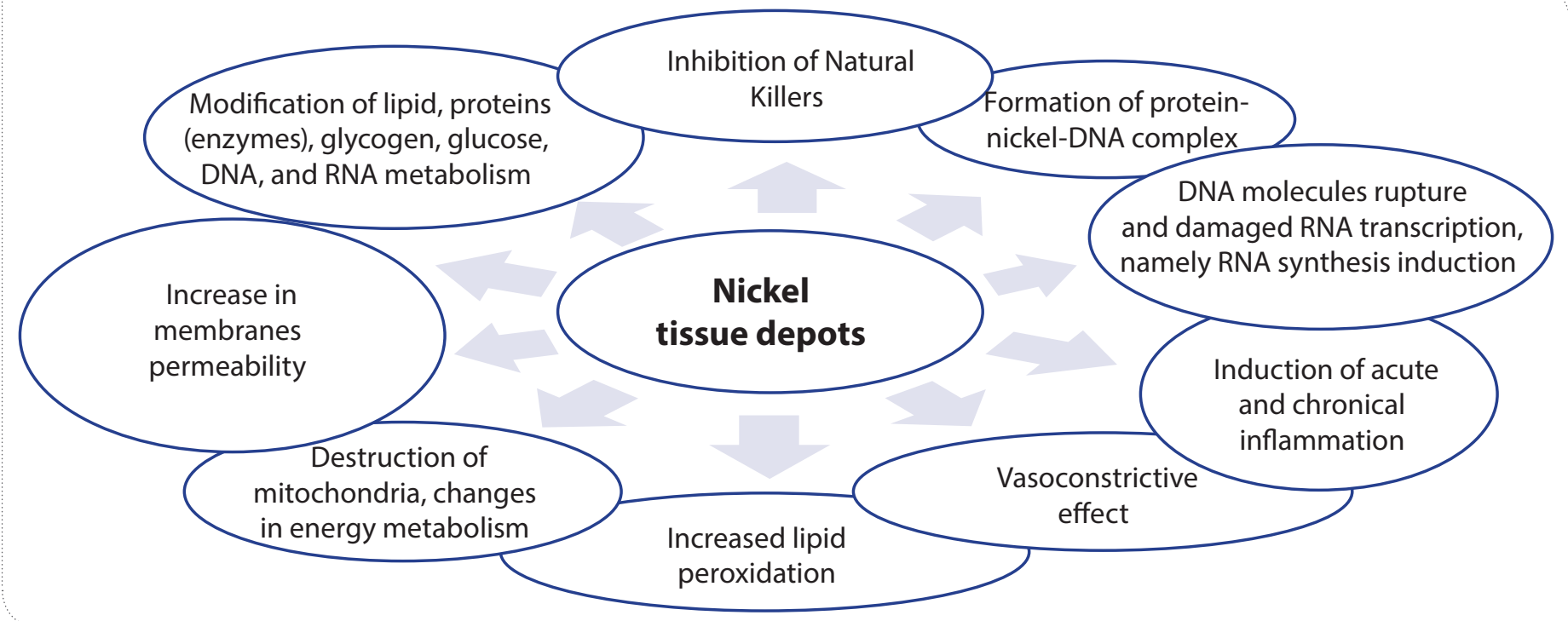


1. State of the Science of Endocrine Disrupting Chemicals - 2012. 7. Zheng, G., Wang, L., Guo, Z., et al. United Nations Environmental Programme and the World Health Organisation, 2013.

2. Legro, R.S., Arslanian, S.A., Ehrmann, D.A., et al. "Endocrine Society. Diagnosis and treatment of polycystic ovary syndrome: an Endocrine Society clinical practice guideline." J Clin Endocrinol Metab 98.12 (2013): 4565-92.

3. World Health Organization.

Trace Elements in Human Nutrition and Health. World Health Organization. Geneva (1996).

4. The Rotterdam ESHRE/ASRM - sponsored PCOS consensus workshop group.

"Revised 2003 consensus on diagnostic criteria and longterm healthrisks related to polycystic ovary syndrome (PCOS)." Hum Reprod 19 (2004): 41-47.

\section{Chakraborty, P., Ghosh, S., Goswami, S.K., et al.}

"Altered trace mineral milieu might play an aetiological role in the pathogenesis of polycystic ovary syndrome." Biol Trace Elem Res 152.1 (2013): 9-15.

6. Kurdoglu, Z., Kurdoglu, M., Demir, H., et al. "Serum trace elements and heavy metals in polycystic ovary syndrome." Hum Exp Toxicol 31.5 (2012): 452-6.
"Association of Serum Heavy Metals and Trace Element Concentrations with Reproductive Hormone Levels and Polycystic Ovary Syndrome in a Chinese Population." Biol Trace Elem Res 167.1 (2015): 1-10.

8. Guler, I., Himmetoglu, 0., Turp, A., et al. "Zinc and homocysteine levels in polycystic ovarian syndrome patients with insulin resistance." Biol Trace Elem Res 158.3 (2014): 297-304.

9. Agency for Toxic Substances and Disease Registry (ATSDR). Toxicological Profile for Chromium. U.S. Department of Health \& Human Services. Public Health Service. Agency for Toxic Substances and Disease Registry. Atlanta, Georgia (2012): 592 p.

10. Coskun, A., Arikan, T., Kilinc, M., et al.

"Plasma selenium levels in Turkish women with polycystic ovary syndrome." Eur J Obstet Gynecol Reprod Biol 168.2 (2013): 183-6.

11. Zagrodzki, P., Krzyczkowska-Sendrakowska, M., Nicol, F. Selenium status parameters in patients with polycystic ovary syndrome Conference: 10th International Symposium on Selenium in biology and Medicine 2013. Berlin, Germany (2013): 41-2.
12. Пыхтеева, Е. Г.

Металлотионеин: биологические функции. Роль металлотионеина в транспорте металлов в организме / Е.Г. Пыхтеева // Актуальні проблеми транспортної медицини: навколишнє середовище; професійне здоров'я; патологія. - 2009. - № 4. - С. 44-58.

Pykhteeva, E.G.

"Metallothionein: biological functions. Metallothionein role in metal transport in the body." Actual Problems of Transport Medicine: environment; occupational health; pathology 4

(2009): 44-58.

13. Чекнёв, С.Б.

Выработка IL-18 в присутствии металлокомплексов ү-глобулина / С.Б. Чекнёв, М.А. Апресова, И.Е. Ефремова, А.А. Бабаянц // Медицинская иммунология. - 2013. № 15 (1).

Cheknev, S.B., Apresova, M.A., Efremova, I.E., Babayants, A.A.

"IL-18 synthesis in the presence of $\gamma$-globulin metal complexes." Medical Immunology 15.1 (2013).

14. Авцын, А.П., Жаворонков, А.А., Риш, М.А., Строчкова, Л.С Микроэлементозы человека. - М.: Медицина. - 1991. - 496 с. Avtsyn, A.P., Zhavoronkov, A.A., Rish, M.A., Strochkova, L.S. Human microelementoses. Moscow. Medicine (1991): 496 p.

\section{SERUM MICRO- AND MACROELEMENTS LEVELS IN WOMEN WITH POLYCYSTIC OVARY SYNDROME ASSOCIATED WITH PELVIC INFLAMMATORY DISEASE}

T.F. Tatarchuk, MD, professor, corresponding member of the NAMS of Ukraine, deputy director for research work, Chief of the Endocrine Gynecology Department, SI"IInstitute of Pediatrics, Obstetrics and Gynecology of the NAMS of Ukraine"

N.V. Kosei, MD, chief researcher at the Endocrine Gynecology Department, State Institution "IInstitute of Pediatrics, Obstetrics and Gynecology of the NAMS of Ukraine"

H.V. Vetokh, obstetrician-gynecologist, Female Consultation Branch № 3, Consultative and Diagnostic Center of the Dniprovskyi district of Kyiv

S.V. Gunkov, PhD, leading researcher, State Enterprise "Scientific Centre of Preventive Toxicology, Nutritional and Chemical Safety named after L.I. Medved"

Polycystic ovary syndrome (PCOS) is the most common endocrinopathies in women of reproductive age.

The aim of the study was to determine the concentrations of some essential macro- and microelements in the body of women with PCOS. Taking into account the frequent combination of PCOS with inflammatory processes of genitals, it was decided to examine trace elements concentration in this category of women.

Study includes 3 groups of women: 30 women with PCOS against the background of inflammatory diseases of pelvic organs (I group), 22 patients with PCOS without inflammatory processes of pelvic organs (II group) and 25 healthy women (III group). In all groups it was studies macro- and microelements concentration in blood: magnesium (Mg), copper (Cu), manganese (Mn), nickel (Ni), zinc (Zn), chromium (Cr), selenium (Se), vanadium (V).

The study revealed increase zinc and nickel level, decrease manganese level in women with $P C O S$, that give grounds suppose their participation in the infringement of folliculogenesis and ovulation due to their properties to intensification of the lipids peroxide oxidation and reduction activity of antioxidant system, injuries cell membranes and mitochondria, gap DNA molecules and to disturb transcription processes. More high zinc and nickel to intensification of the lipids peroxide oxidation and reduction activity of antioxidant system, injuries cell membranes and mitochondria, gap DNA molecules and to disturb transcription processes. More high zinc and nickel
concentrations in patients with PCOS in the background of inflammatory process indicates on possible inflammation role in disorders development, because proinflammatory cytokines (IL-1, L-6, IL-18, TNF-a) leads to the zinc accumulation and elevated nickel concentrations can induce inflammation and inhibit the functional activity of macrophages and natural killer cells, setting the conditions for chronic inflammation.

Level study of trace elements (zinc, nickel and manganese) may be recommended for women with PCOS and with inflammatory diseases of pelvic organs and control their administration in complex multivitamin preparations. Keywords: polycystic ovary syndrome, inflammatory diseases of pelvic organs, manganese, nickel, zinc.

\section{ВМІСТ МІКРО- ТА МАКРОЕЛЕМЕНТІВ У КРОВІ ЖІНОК ІЗ СИНДРОМОМ ПОЛІКІСТОЗНИХ ЯЕЧНИКІВ НА ФОНІ ЗАПАЛЬНИХ ЗАХВОРЮВАНЬ ОРГАНІВ МАЛОГО ТАЗУ}

Т.Ф. Татарчук, Д. мед. н., професор, член-кор. НАМН України, заст. директора з наукової роботи, зав. відділенням ендокринної гінекології ДУ «ІПАГ НАМН України»

Н.В. Косей, д. мед. н., гол. наук. співробітник відділення ендокринної гінекології ДУ «ІПАГ НАМН України»

Г.В. Вєтох, акушер-гінеколог жіночої консультації філіалу № 3 Консультативно-діагностичного центру Дніпровського району м. Києва

С.В. Гуньков, к. мед. н., провідний наук. співробітник ДП «Науковий центр превентивної токсикології, харчової та хімічної безпеки ім. Л.І. Медведя»

Синдром полікістозних яєчників (СПКЯ) є найчастішою ендокринопатією в жінок репродуктивного віку.

Метою дослідження стало визначення концентрацій деяких ессенціальних макро- та мікроелементів в організмі жінок із СПкя. Враховуючи досить часте поєднання СПКя із запальними процесами геніталій, було вирішено дослідити вміст мікроелементів також у цій категорії жінок.

Для дослідження було вибрано 3 групи жінок: 30 жінок із СПКЯ на фоні запальних захворювань органів малого тазу (I група), 22 пацієнтки з СПКя на фоні відсутності запальних процесів геніталій (II група) та 25 здорових жінок (III група). В усіх групах жінок ми вивчали вміст макро- та мікроелементів в сироватці крові: магнію (Mg), міді (Cu), марганцю (Mn), нікелю (Ni), цинку (Zn), хрому (Cr), селену (Se), ванадію (V).

Проведене дослідження виявило підвищення рівнів цинку та нікелю, зниження рівня марганцю за умов наявності СПКя, що дає підстави припустити ї участь у порушенні процесів фолікулогенезу та овуляції, зважаючи на відомі властивості цих мікроелементів щодо активізації перекисного окислення ліпідів та зниження активності антиоксидантної системи, пошкодження клітинних мембран та мітохондрій, розриву молекул ДНК і порушення процесів транскрипції. Дещо вищі концентрації цинку та нікелю в пацієнток із СПкя на фоні запального процесу вказують на можливу роль запалення у механізмі розвитку порушень, адже прозапальні цитокіни (інтерлейкінів 1-го, 6-го, 18-го типів, фактору некрозу пухлин а) сприяють накопиченню цинку, а підвищені концентрації нікелю можуть індукувати запалення та пригнічувати функціональну активність макрофагів та натуральних кілерів, створюючи умови для хронізації запального процесу.

Зважаючи на викладене вище, можна рекомендувати обстеження жінок із СПКя за умов поєднання його із запальними захворюваннями геніталій на вміст мікроелементів, зокрема, цинку, нікелю і марганцю та контролювати їх введення у складі комплексних полівітамінних препаратів.

Ключові слова: синдром полікістозних яєчників, запальні захворювання органів малого тазу, марганець, нікель, цинк.

\section{СОДЕРЖАНИЕ МИКРО- И МИКРОЭЛЕМЕНТОВ В КРОВИ ЖЕНЩИН С СИНДРОМОМ ПОЛИКИСТОЗНЫХ ЯИЧНИКОВ НА ФОНЕ ВОСПАЛИТЕЛЬНЫХ ЗАБОЛЕВАНИЙ ОРГАНОВ МАЛОГО ТАЗА}

Т.Ф. Татарчук, Д. мед. Н., профессор, член-корр. НАМН Украины, зам. директора по научной работе, зав. отделением эндокринной гинекологии ГУ «ИПАГ НАМН Украины»

Н.В. Косей, Д. мед. н., глав. науч. сотрудник отделения эндокринной гинекологии ГУ «ИПАГ НАМН Украины»

Г.В. Ветох, акушер-гинеколог женской консультации филиала № 3 Консультативно-диагностического центра Днепровского района г. Киева

С.В. Гуньков, к. мед. н., ведущий научный сотрудник ГП «Научный центр превентивной токсикологии, пищевой и химической безопасности им. Л.И. Медведя»

Синдром поликистозных яичников (СПКя) является частой эндокринопатией у женщин репродуктивного возраста.

Целью исследования стало определение концентраций некоторых эссенциальных макро- и микроэлементов в организме женщин с Спкя. Учитывая достаточно частое сочетание спкя своспалительными процессами гениталий, было решено исследовать содержание микроэлементов также в этой категории женщин.

Для исследования было выбрано 3 группы женщин: 30 женщин с СПКя на фоне воспалительных заболеваний органов малого таза (I группа), 22 пациентки с СПКя на фоне отсутствия воспалительных процессов гениталий (II группа) и 25 здоровых женщин (III группа). Во всех группах женщин мы изучали содержание макро- и микроэлементов в сыворотке крови: магния (Мg), меди (Сu), марганца (Мn), никеля (Ni), цинка (Zn), хрома (Cr), селена (Se), ванадия (V).

Проведенное исследование выявило повышение уровня цинка и никеля, снижение уровня марганца при условии наличия СПКя, что дает основания предположить их участие в нарушении процессов фолликулогенеза и овуляции, исходя из известных свойств этих микроелементов в отношении активизации перекисного окисления липидов и снижения активности антиоксидантной системы, повреждения клеточных мембран и митохондрий, разрыва молекул ДНК и нарушения процессов транскрипции. Несколько более высокие концентрации цинка и никеля у пациенток с СПкЯ на фоне воспалительного процесса указывают на возможную роль воспаления в механизме развития нарушений, ведь провоспалительные цитокины (интерлейкинов 1-го, 6-го, 18-го типов, фактора некроза опухолей а) способствуют накоплению цинка, а повышенные концентрации никеля могут индуцировать воспаления и подавлять функциональную активность макрофагов и натуральных киллеров, создавая условия для хронизации воспалительного цинка, а повь процесса.

Можно рекомендовать обследование женщин с СПкя в условиях сочетания его с воспалительными заболеваниями гениталий на содержание микроэлементов, в частности, цинка, никеля и марганца и контролировать их введение в составе комплексных поливитаминных препаратов.

Ключевые слова: синдром поликистозных яичников, воспалительные заболевания органов малого таза, марганец, никель, цинк. 